\title{
Haematology of gynogenetic diploids of Siberian sturgeon Acipenser baerii Brandt
}

\author{
Dorota Fopp-Bayat, Teresa Wlasow, Elzbieta Ziomek \\ Department of Ichthyology, University of Warmia and Mazury in Olsztyn, Poland
}

Received June 18, 2012

Accepted October 23, 2012

\begin{abstract}
Haematological analyses were conducted in gynogenetic diploids and control diploids of Siberian sturgeon (Acipenser baerii). Gynogenetic diploid fish were obtained from Polish aquaculture after induction of meiotic gynogenesis based on application of UV-irradiated hybrid Siberian sturgeon $\times$ Russian sturgeon (A. gueldenstaedtii) sperm (for eggs activation) and heat shock for inhibiting the second polar body retention. A total of fifteen 30-month-old specimens of Siberian sturgeon from the gynogenetic diploid group and 12 specimens from the control diploid group were randomly sampled. There were no differences in the number of erythrocytes and haematocrit values between gynogenetic diploids and normal diploids of Siberian sturgeon. However, the percentage of normal erythrocytes was lower in the gynogenetic group of fish and the higher percentage of the atypical red blood cell forms (microcytes, sphaerocytes, erythrocytes with displaced nuclei and with divided nuclei) were observed in this group of fish. Additionally all the haemoglobin indices (haemoglobin concentration, the mean corpuscular haemoglobin and the mean corpuscular haemoglobin concentration) were significantly reduced in gynogenetic diploids of Siberian sturgeon. These results could suggest depletion of oxygenation capacity of the blood of gynogenetic sturgeons. This is the first report of a haematological study in gynogenetic diploids of sturgeon fish.
\end{abstract}

Acipenseridae, gynogenesis, haematological indices, red blood cells, white blood cells

Among sturgeon fish, the Siberian sturgeon is one of the most popular species in European aquaculture. The farming of this species began in the former USSR in the 1970s (Food and Agriculture Organization of the United Nations; FAO 2005). Generally, sturgeons are valuable for two products: tasteful and boneless meat, and the black caviar. The main problem in sturgeon aquaculture is a long period of sexual maturation, and difficulty obtaining a breeding stock with sufficient number of females (Fopp-Bayat et al. 2006). This problem can be resolved by producing all-female stocks of sturgeon using genome manipulation such as gynogenesis.

Gynogenesis relates to the inheritance of maternal genetic material only. This technique involves the activation of egg development by genetically inactive spermatozoa and diploidy restoration (Pandian and Koteeswaran 1998; Arai 2001; Paschos et al. 2001; Komen and Thorgaard 2007).

Gynogenesis on sturgeon fish is very useful because it enables creation of sturgeon female fish stock for production of black caviar. This technique was successfully induced in sturgeon fish, e.g. in white sturgeon (Van Eenennaam et al. 1996), sterlet (Fopp-Bayat et al. 2007) and Siberian sturgeon (Fopp-Bayat 2007; Fopp-Bayat 2010). Although gynogenesis was conducted on several sturgeon species, there is no information on the blood cells or haematological analyses in gynogenetic offspring.

Therefore, the aim of the present study was to investigate the haematological indices and morphological characteristics of peripheral blood cells of gynogenetic diploid Siberian sturgeon.

\section{Materials and Methods}

The gynogenetic diploids ( 15 specimens with an average body weight of $259 \mathrm{~g}$ ) and control diploids (12 specimens with an average body weight of $401 \mathrm{~g}$ ) used in the present study belonged to the same parents of Siberian sturgeon Acipenser baerii Brandt (one female and one male). The induction of meiotic gynogenesis

Address for correspondence:

Dr hab. Dorota Fopp-Bayat

Department of Ichthyology, Faculty of Environmental Sciences

University of Warmia and Mazury, Oczapowskiego 5, 10- 719 Olsztyn, Poland
Phone: +48895234772
Fax: +48 895233754
E-Mail: foppik@uwm.edu.pl
http://actavet.vfu.cz/ 
was conducted based on the protocol described by Fopp-Bayat (2007). Ploidy of the fish was confirmed by cytogenetic analysis (Fopp-Bayat et al. 2006). All the studied fish (from gynogenetic diploid group and control diploid group) possessed about 240 chromosomes (from 229 to 240 chromosomes in particular analyzed metaphase plates) that was typical chromosome number for normal diploid Siberian sturgeon (Fontana 2002). The induction of gynogenesis was conducted in the Wasosze fish farm near Konin, Poland. The fish were reared at an aquaculture facility. Blood was collected both from a total of fifteen 30-month-old gynogenetic diploids and 12 control diploid Siberian sturgeons. The fish were anaesthetized with Propiscin $(0.2 \%$ stabilized solution of etomidate; $2 \mathrm{ml} \cdot \mathrm{l}^{-1}$, made by IRS, Poland) and the peripheral blood was collected under sterile conditions by puncture of the caudal vessels with a heparin-coated gauge needle attached to a $2.5 \mathrm{ml}$ syringe.

Values of the erythrocyte count (RBC), haemoglobin concentration (Hb), haematocrit (PCV), mean corpuscular volume $(\mathrm{MCV})$, the mean corpuscular haemoglobin $(\mathrm{MCH})$ and the mean corpuscular haemoglobin concentration (MCHC) were determined by standard methods (Svobodová et al. 1991). In each fixed and dyed preparation, 500 red cells and 200 white blood cells were analyzed. The following forms of red blood cells were considered: normal erythrocytes, sphaerocytes, microcytes (demonstrably smaller red blood cells), erythrocytes with a displaced nucleus, erythrocytes with a divided nucleus, and erythroplastids (without nuclei). Normal oval shape erythrocytes with central localized nucleus, spherocytes (the spherical red blood cells smaller than normal red blood cells), microcytes (demonstrably smaller red blood cells) were observed under a microscope.

Table 1. Haematological indices of gynogenetic diploids and diploids of Siberian sturgeon.

\begin{tabular}{lccc}
\hline $\begin{array}{l}\text { Indices } \\
\text { and units }\end{array}$ & $\begin{array}{c}\text { Gynogenetic } \\
\text { diploids }(\mathrm{n}=15)\end{array}$ & $\begin{array}{c}\text { Diploids - control } \\
(\mathrm{n}=12)\end{array}$ & $P$ \\
\hline $\mathrm{RBC}\left(\mathrm{T} \cdot \mathrm{l}^{-1}\right)$ & $0.87 \pm 0.03$ & $0.87 \pm 0.02$ & $\mathrm{~N}$ \\
$\mathrm{PCV}\left(1 \cdot \mathrm{l}^{-1}\right)$ & $0.31 \pm 0.01$ & $0.32 \pm 0.02$ & $\mathrm{~N}$ \\
$\mathrm{Hb}\left(\mathrm{g} \cdot \mathrm{l}^{-1}\right)$ & $64.80 \pm 3.80$ & $72.75 \pm 1.69$ & $<0.001$ \\
$\mathrm{MCV}(\mathrm{fl})$ & $350.47 \pm 8.25$ & $361.34 \pm 9.57$ & $<0.005$ \\
$\mathrm{MCH}(\mathrm{pg})$ & $74.04 \pm 2.51$ & $83.46 \pm 1.51$ & $<0.001$ \\
$\mathrm{MCHC}\left(1 \cdot \mathrm{l}^{-1}\right)$ & $0.21 \pm 0.01$ & $0.23 \pm 0.01$ & $<0.001$ \\
\hline
\end{tabular}

Data presented as average value $\pm \mathrm{SD}$ (standard deviation), $P$ - statistical significance, N- non-significant, RBC- erythrocyte count, $\mathrm{Hb}$ - haemoglobin concentration, $\mathrm{PCV}$ - haematocrit, $\mathrm{MCV}$ - mean corpuscular volume, $\mathrm{MCH}$ - the mean corpuscular haemoglobin, $\mathrm{MCHC}$ - mean corpuscular haemoglobin concentration

Table 2. Comparison of the percentage of red blood cell forms of gynogenetic diploids and diploids of Siberian sturgeon (average value $\pm \mathrm{SD}$ ).

\begin{tabular}{|c|c|c|c|}
\hline $\begin{array}{l}\text { Forms } \\
\text { of erythrocytes }\end{array}$ & $\begin{array}{c}\text { Gynogenetic } \\
\text { diploids }(n=15)\end{array}$ & $\begin{array}{l}\text { Diploids - control } \\
\quad(\mathrm{n}=12)\end{array}$ & $P$ \\
\hline Typical & $57.68 \pm 5.14$ & $85.99 \pm 3.84$ & $<0.001$ \\
\hline Microcytes & $11.82 \pm 3.24$ & $3.18 \pm 1.15$ & $<0.001$ \\
\hline Sphaerocytes & $1.45 \pm 0.39$ & $0.94 \pm 0.0 .37$ & $<0.005$ \\
\hline E with displaced nuclei & $14.06 \pm 2.99$ & $5.67 \pm 2.32$ & $<0.001$ \\
\hline E with the divided nucle & & & \\
\hline into two parts & $2.70 \pm 2.51$ & $0.00 \pm 0.00$ & $<0.005$ \\
\hline E with the divided nucle & & & \\
\hline into three parts & $2.01 \pm 1.42$ & $0.00 \pm 0.00$ & $<0.001$ \\
\hline $\begin{array}{l}\text { E with the divided nucle } \\
\text { into } \geq \text { four parts }\end{array}$ & $1.25 \pm 0.69$ & $0.30 \pm 0.65$ & $<0.005$ \\
\hline $\begin{array}{l}\text { E with the atypical shape } \\
\text { of nuclei }\end{array}$ & $5.67 \pm 3.80$ & $1.93 \pm 0.97$ & $\mathrm{~N}$ \\
\hline Erythroplastids & $1.48 \pm 2.09$ & $3.72 \pm 10.33$ & $\mathrm{~N}$ \\
\hline Shadow forms & $2.47 \pm 2.92$ & $1.77 \pm 1.34$ & $\mathrm{~N}$ \\
\hline
\end{tabular}

Data presented as average value $\pm \mathrm{SD}$ (standard deviation), $\mathrm{E}$ - erythrocytes, $P$ - statistical significance, $\mathrm{N}-$ nonsignificant 
Among white blood cells, the following forms were analyzed: lymphocytes, myelocytes, neutrophile granulocytes $(\mathrm{PMN})$ with a rod-shaped nucleus, PMN with a 2-, 3- and 4- and more segments of nuclei, eosinophilic granulocytes: with a rod-shaped nucleus, with a nucleus divided into 2, 3 and $>3$ segments.

The results were analyzed statistically, using Student's $t$-test $(P=0.05)$.

\section{Results}

There were no differences in the number of erythrocytes and haematocrit values in gynogenetic diploid and diploid Siberian sturgeons (Table 1). However, the mean corpuscular volume, haemoglobin concentration, mean corpuscular haemoglobin, and mean corpuscular haemoglobin concentration were significantly depressed in the gynogenetic diploid fish (Table 1). Among the red blood cells, percentage of normal erythrocytes was depressed in gynogenetic diploids in contrast to control sturgeons (Table 2). Microcytes, sphaerocytes, erythrocytes with displaced nuclei, erythrocytes with divided nuclei (into two and more parts) were significantly frequent $(P<0.001, P<0.005$; Table 2$)$. A significant increase of neutrophile granulocytes with 2, 3, 4 and more segments of nuclei was observed in the gynogenetic diploid Siberian sturgeon $(P<0.001, P<0.05$; Table 3$)$.

Table 3. Comparisons of the percentage of white blood cell forms in gynogenetic diploids and diploids of Siberian sturgeon.

\begin{tabular}{lccc}
\hline $\begin{array}{l}\text { Forms of } \\
\text { white blood cells }\end{array}$ & $\begin{array}{c}\text { Gynogenetic } \\
\text { diploids }(\mathrm{n}=15)\end{array}$ & $\begin{array}{c}\text { Diploids }- \text { control } \\
(\mathrm{n}=12)\end{array}$ & $P$ \\
\hline Lymphocytes & $56.02 \pm 1.91$ & $60.10 \pm 5.81$ & $\mathrm{~N}$ \\
Myelocytes & $3.63 \pm 0.9$ & $3.08 \pm 0.71$ & $\mathrm{~N}$ \\
$\begin{array}{l}\text { Neutrophile granulocytes } \\
\quad \text { with rods nuclei }\end{array}$ & $5.95 \pm 1.28$ & $4.68 \pm 1.22$ & $\mathrm{~N}$ \\
$\quad$ with 2 segments of nuclei & $12.36 \pm 1.65$ & $8.93 \pm 2.32$ & $<0.001$ \\
$\quad$ with 3 segments of nuclei & $16.60 \pm 1.92$ & $14.51 \pm 2.85$ & $<0.05$ \\
$\quad$ with $\geq$ 4 segments of nuclei & $4.61 \pm 2.06$ & $7.92 \pm 5.15$ & $\mathrm{~N}$ \\
Eosinophilic granulocytes & & & $\mathrm{N}$ \\
$\quad$ with rods nuclei & $0.17 \pm 0.24$ & $0.42 \pm 0.49$ & $\mathrm{~N}$ \\
$\quad$ with 2 segments of nuclei & $0.30 \pm 0.49$ & $0.13 \pm 0.20$ & \\
with 3 segments of nuclei & $0.23 \pm 0.32$ & $0.04 \pm 0.13$ & \\
\hline
\end{tabular}

Data presented as average value $\pm \mathrm{SD}$ (standard deviation), $\mathrm{N}$ - non-significant, $P$ - statistical significance

\section{Discussion}

Our study presents the first report on blood cells in gynogenetic diploids of Siberian sturgeon. The gynogenetic fish was characterized by similar values of haematocrit and erythrocyte number. Significant reduction of all haemoglobin indices $(\mathrm{Hb}, \mathrm{MCH}$ and $\mathrm{MCHC}$ ) in the peripheral blood of gynogenetic diploid fish suggested oxygenation capacity of the blood depletion. No immature red blood cells were found, which were frequently observed in triploid Siberian sturgeons (Wlasow and Fopp-Bayat 2011). The mean corpuscular volume of red cells in gynogenetic diploid Siberian sturgeons was reduced in comparison to control, and the percentage of small erythrocytes (microcytes) was increased. In red cell profile of gynogenetic diploids, significant dominance of erythrocytes with a displaced nucleus occurred. Erythrocytes with eccentric nuclei are at the process stage called enucleation (Ellis 1984). The percentage (14\%) of red cells with a displaced nucleus found in the gynogenetic fish in our study was higher compared to $10 \%$ in triploid 
A. baeri (Wlasow and Fopp-Bayat 2011). In the present study such erythrocytes could be considered as a source of microcytes because the percentage of enucleated red cells was small.

The blood of triploid Siberian sturgeon was characterized by significant dominance of immature red blood cells, erythrocytes with a displaced nucleus, microcytes, erythroplastids and a depressed share of lymphocytes (Wlasow and Fopp-Bayat 2011). In contrast, there was no difference in the number of lymphocytes in gynogenetic diploids compared to the control diploids in our study. The reduction of erythrocytes and leukocytes, and undesirable changes in both red and white blood cells were observed also in triploid fish (Svobodova et al. 1998; Benfey 1999; Wlasow et al. 2004). In the triploid tench, occurrence of granulocytes with segmented nucleus was observed more frequently than in diploid fish (Svobodova et al. 2001).

The percentage of lymphocytes in the diploid group of fish in our study $(60.10 \pm 5.81)$ was similar to the results in Siberian sturgeon described by Palikova et al. (1999). The blood of gynogenetic sturgeon in our study was characterized by an increase of frequency neutrophile with segmented nuclei ( 2 and 3 segments).

In a study by Flajshans and Vajcova (2003), the blood of gynogenetic tench was characterized by higher erythrocyte counts than diploid control and had higher blood haemoglobin content. There were no differences in haematocrit, mean corpuscular haemoglobin and mean corpuscular volume among the studied strains of tench. The gynogenetic tench was also characterized by a significantly high content of neutrophil granulocytes compared to the control group of fish. A similar effect was observed in the Siberian sturgeon in our study. The highest and most variable frequency of neutrophiles may indicate some early and not-yet specified immature reaction of studied specimens (Flajshans and Vajcova 2003).

Knowledge of haematological indices of gynogenetic fish, especially sturgeon, is limited so this research is scientifically important. However, further studies should be extended to biochemical analysis.

\section{Acknowledgement}

The study was supported by the project 08040809 of University of Warmia and Mazury in Olsztyn, Poland.

\section{References}

Arai K 2001: Genetic improvement of aquaculture finfish species by chromosome manipulation techniques in Japan. Aquaculture 197: 205-228

Benfey TJ 1999: The physiology and behavior of triploid fishes. Rev Fish Sci 7: 39-67

Ellis AE 1984: Bizzare forms of erythrocytes in a specimen of plaice, Pleuronectes platessa L. J Fish Dis 7 : 411-414

FAO 2005. Cultured Aquatic Species Information Programme Acipenser baerii (Brandt, 1869). http://www.fao. org/fishery/culturedspecies/Acipenser baerii/en

Flajshans M, Vajcova V 2003: The haematology of gynogenic tench, Tinca tinca L., and of recessively homozygous colour tench strains. J Appl Ichthyol 19: 170-173

Fontana F 2002: A cytogenetic approach to the study of taxonomy and evolution in sturgeons. J Appl Ichthyol 18: $226-233$

Fopp-Bayat D 2007: Verification of meiotic gynogenesis in Siberian sturgeon (Acipenser baeri) using microsatellite DNA and cytogenetical markers. J Fish Biol 77: 478-485

Fopp-Bayat D 2010: Meiotic gynogenesis revealed not homogametic female sex determination system in Siberian sturgeon (Acipenser baeri Brandt). Aquaculture 305: 174-177

Fopp-Bayat D, Jankun M, Woznicki P 2006: Chromosome number and erythrocyte nuclei length in triploid Siberian sturgeon Acipenser baeri Brandt. Caryologia 59: 319-321

Fopp-Bayat D, Kolman R, Woznicki P 2007: Induction of meiotic gynogenesis in sterlet (Acipenser ruthenus). Aquaculture 264: 54-58

Komen H, Thorgaard GH 2007: Androgenesis, gynogenesis and the production of clones in fishes: A review. Aquaculture 269: 150-173 
Palikova M, Mares J, Jirasek J 1999: Characteristics of leukocytes and thrombocytes of selected sturgeon species from intensive breeding. Acta Vet Brno 68: 259-264

Pandian TJ, Koteeswaran R 1998: Ploidy induction and sex control in fish. Hydrobiologia 384: 167-243

Paschos I, Natsis L, Nathanailides C, Kagalou I, Kolettas E 2001: Induction of gynogenesis and androgenesis in goldfish Carassius auratus (var. oranda). Reprod Domest Anim 36: 195-198

Svobodová Z, Flajšhans M, Kolárová J, Modrá H, Svoboda M, Vajcová V 2001: Leukocyte profiles of diploid and triploid tench, Tinca tinca L. Aquaculture 198: 159-168

Svobodová Z, Kolarova J, Flajshans M 1998: The first findings of the differences in complete blood count between diploid and triploid tench, Tinca tinca L. Acta Vet Brno 67: 243-248

Svobodová Z, Pravda D, Paláčková J 1991: Unified methods of haematological examination of fish. Research Institute of Fish Culture and Hydrobiology, Vodnany, $31 \mathrm{p}$.

Van Eenennaam AL, Van Eenennaam JP, Medrano JF, Doroshov SI 1996: Rapid verification of meiotic gynogenesis and polyploidy in white sturgeon (Acipenser transmontanus Richardson). Aquaculture 147: 177-189

Wlasow T, Fopp-Bayat D 2011: The effect of thermal shock on morphological characteristics of blood cells in Siberian sturgeon (Acipenser baerii) triploids. Acta Vet Brno 80: 171-175

Wlasow T, Kuzminski H, Woznicki P, Ziomek E 2004: Blood cells alteration in triploid brook trout Salvelinus fontinalis (Mitchill). Acta Vet Brno 73: 115-118 